\title{
Diversity Among Selected Caste and Tribal Groups of Western India: Origin, HLA and Disease Associations
}

\author{
U.Shankarkumar \\ HLA Department, Institute of Immunohaematology (ICMR), $13^{\text {th }}$ Floor, NMS Bldg, \\ K.E.M.Hospital, Parel, Mumbai 400 012, Maharashtra, India \\ Fax:91-22-4138521, Email: Shankarkumar16@hotmail.com
}

KEYWORDS Caste groups; tribal groups; HLA antigens; disease associations

\begin{abstract}
Indian population is well known for its genetic diversity. Among the numerous endogamous communities, which is restricted very much by custom, marriage and occupation, a compiled analysis of 1742 individuals comprising of different caste and tribes from Maharastra Western India is presented. The sympatrically isolated caste and tribal population of western India with different origins, migration pattern and breeding habits differed significantly in their HLA and also in their HLA allele (Relative risk) prevalence for a number of disease associations. Further the analysis reveal that the caste groups of India cannot be considered as a single panmictic population with reference to genetic characteristics, which may have a clinical relevance in unrelated donor selection for allogenic Bone marrow transplantation and disease associations in India.
\end{abstract}

\section{INTRODUCTION}

The caste system in India (Bhasin and Walter 2001) is characterized by class exogamy and caste endogamy and in biological terms each caste/ tribe is a breeding isolate. Having differed in origin, migration, linguistics, socio-cultural aspects and settlement these populations diverged further. Whether such sympatric breeding isolates would be differentially susceptible to a given epidemic in a given region/ city, or be subject to similar evolutionary pressures, requires an understanding of evolutionary principles. In drawing lessons from community genetics, one has to remember that the gene pool, linguistics and culture can be regarded as three independent entities which may overlap in terms of time, space, origin and spread, but not as a rule. By virtue of their immune repertoire, the diverse gene pools of India may not be equally susceptible to an epidemic of infection. Different genes may be involved in different population (Hill 1998).

\section{THE HLA SYSTEM}

The HLA system, most polymorphic and complex set of genetic markers known in man, is of valuable significance in anthropological studies (Bhasin et al. 1994). These cell-surface antigens play an important role in the activation of immune competent cells, thereby promoting immune response. The extensive polymorphism of the HLA system is associated with a large peptide repertoire for initiating immune responses against a wide range of foreign antigens (pathogens). They also have useful application in the study of the origin, evolution and migration patterns of human populations. Distribution of HLA antigens in various population groups of the India has been reported (Pitchappan et al. 1984; Rajasekar et al. 1987; Balakrishnan et al. 1996; Agrawal et al. 1999; Shankarkumar et al. 1999; Chayya et al. 2000; Jaini et al. 2002). For the indigenous caste/tribal populations of India practically very little information on the distribution of HLA antigens exists. The present study is the first population genetic analyses of HLA antigens in endogamous caste and tribal groups of Western India. Population specific distribution of HLA alleles is necessary and interesting both in population genetics and in HLA disease association studies (Bodmer 1987). Large number of this kind of studies have other uses e.g. Likelihood of finding an unrelated HLA compatible stem cell donor for allogenic stem cell transplantation and also for constructing a National stem cell registry in India. The Indian population differs in their origin, migration and settlement, which correlate to the advent of social stratification and caste system which, dates back to the existence of human societies in the Eurasian steppes. Analysis of genetic data 
suggests that the inhabitants of the Western part of the Eurasian steppes, originally settled by Caucasoid people speaking Indo-European languages, migrated in various directions, including Iran and India. It is believed that these pastoral nomads often generated hierarchical societies and introduced the caste system in Indian subcontinent (Cavali-Sforza et al. 1993).

\section{Western Indian Community}

HLA distribution from 1742 healthy individuals belonging to different caste and tribal groups from Maharastra was compiled in Table 1 and Table 2. The origin and caste/tribe details of these populations reported are explained in detail elsewhere (Einthoven 1990). The HLA alleles associated among these population groups with various diseases have been presented in Table 3.

\section{HLA Typing}

Ten to fifteen milliliters of venous blood (in heparin $50 \mathrm{IU} / \mathrm{ml}$ ) was collected in a sterile tube from each individual after obtaining ethical consent. The lymphocytes were isolated by density gradient centrifugation on Histopaque (Boyum 1968). HLA A, B, C and DR locus antigens were identified by NIH two - stage Microlymphocytotoxicity assay (Terasaki and McClelland 1964) using T cells for class I typing and $\mathrm{B}$ cells isolated by a miniature nylon wool column for class II with a longer incubation period (Manikasundari et al. 1984). A total of 190 indigenous (Shankarkumar et al 1998) as well as commercially procured antisera were used for defining 17 specificities for HLA A locus, 29 for HLA B locus, 8 for HLA C locus and 10 for HLA DR locus antigens. The typing tray included a minimum of three antisera for each supertypic specificity. Further the molecular typing of HLA alleles were done using the extracted genomic DNA and the Polymerase chain reaction sequence specific priming (PCR-SSP) kits.

\section{Statistical Analysis}

The phenotype frequencies, gene frequencies, relative risks (Shankarkumar et al. 2002) presented in Tables 1, 2 and 3 were estimated using our database and computer programs. Since each individual is tested for several HLA alleles and the same data used for comparing the frequency; it is possible that one of the alleles will by chance deviate significantly. To overcome this error, the $\mathrm{P}$ value is corrected by use of Bonferoni inequality method (Dunn 1961) i.e. by multiplying it with the number of alleles compared and the quality of the study design was assessed from the published data.

Theoretically high polymorphism of a gene can occur due to mutation rate, selection, genetic hitchhiking or a combination of all the three (Kaufman 1996). Indigenous populations or caste/tribal groups show a very restricted diversity of alleles at a particular HLA loci consistent within a population. Moreover specific alleles found uniquely in a particular indigenous group as HLA B48 among Patels caste, B14 among Parsis and Badaga tribes, B21 among Koya tribe etc. may have been generated by point mutation or gene conversion from the ancestral allele after the group separated from the other groups (Shankarkumar et al. 2002). Multiple polymorphic alleles in a population are maintained at appreciable frequencies due to either overdominance (heterozygous advantage), frequency dependent selection, bottleneck effect or other selective forces (Shankarkumar et al. 2002). Both selective forces and a high rate of germline diversification are involved in the evolution of HLA allelic diversity.

\section{Immunological Diversity: Are They Evolutionary?}

The immune system is the most important biological system affected by the evolutionary pressures of diseases and is characterized by very high levels of polymorphism. The implications of these polymorphic diversities are important in community genetics in general and western India in particular, given the variation in HLA allele repertoires of various western Indian caste (Table 1) and tribal (Table 2) populations. The tables show the frequencies of various alleles in different regions of Western India, stratified data based on the exact caste and tribal groups revealed greater diversity and genetic distances equivalent to two globally distant populations (Shankarkumar et al. 1999; Shankarkumar et al. 2000; Chayya and Shankarkumar 2001). The numerical strength and spatial distribution of various exogamous clan of a caste/ tribe decides the marriageable range which defines the gene pool. Our study on the Brahmins from Maharastra 
HLA DIVERSITY AND DISEASE ASSOCIATIONS IN WESTERN INDIA

Table 1: Percentage frequencies among different Western Indian caste groups

\begin{tabular}{|c|c|c|c|c|c|c|c|c|c|c|c|}
\hline $\begin{array}{l}H L A \\
R e f \\
N=965\end{array}$ & $\begin{array}{r}\text { Banya } \\
15 \\
N-78\end{array}$ & $\begin{array}{r}\text { Lohana } \\
15 \\
N-46\end{array}$ & $\begin{array}{r}\text { Brahmin } \\
18 \\
N-54\end{array}$ & $\begin{array}{r}\text { Maratha } \\
20 \\
N-289\end{array}$ & $\begin{array}{r}\text { Jains } \\
19 \\
N-161\end{array}$ & $\begin{array}{r}C K P \\
15 \\
N-50\end{array}$ & $\begin{array}{r}\text { Kunbi } \\
18 \\
N-26\end{array}$ & $\begin{array}{c}\text { Mahar } \\
18 \\
N-32\end{array}$ & $\begin{array}{c}\text { ajpathi } \\
15 \\
N-50\end{array}$ & $\begin{array}{r}\text { Parsee } \\
15 \\
N-67\end{array}$ & $\begin{array}{r}\text { Patels } \\
15 \\
N-112\end{array}$ \\
\hline$\overline{\mathrm{A} 1}$ & 24.4 & 21.7 & 46.3 & 28.37 & 32.3 & 16 & 15.4 & 25 & 16 & 22.4 & 45.5 \\
\hline A2 & 35.9 & 23.9 & 16.7 & 30.8 & 22.4 & 30 & 53.8 & 40.6 & 30 & 9 & 31.3 \\
\hline A 3 & 21.8 & 26.1 & 22.2 & 9 & 19.3 & 20 & 3.8 & 9.4 & 20 & 4.5 & 22.3 \\
\hline A9 & 33.3 & 28.3 & 24.1 & 25.26 & 36 & 64 & 50 & 28.1 & 64 & 67.2 & 40.2 \\
\hline A 10 & 9 & 23.9 & 11.1 & 8.3 & 13.7 & 0 & 11.5 & 6.3 & 0 & 14.9 & 7.1 \\
\hline A 11 & 20.5 & 19.6 & 24.1 & 24.57 & 24.2 & 10 & 11.5 & 18.8 & 10 & 14.9 & 33 \\
\hline A 19 & 10.3 & 26.1 & 14.8 & 21.11 & 15.5 & 56 & 42.3 & 53.1 & 56 & 62.7 & 10.7 \\
\hline A28 & 12.8 & 13 & 9.3 & 12.8 & 16.1 & 0 & 7.7 & 12.5 & 0 & 0 & 0 \\
\hline B5 & 41 & 23.9 & 38.9 & 17.3 & 36 & 54 & 15.4 & 12.5 & 54 & 29.9 & 28.6 \\
\hline B7 & 7.7 & 13 & 22.2 & 23.88 & 4.3 & 26 & 23.1 & 28.1 & 26 & 3 & 13.4 \\
\hline B8 & 10.3 & 10.9 & 3.7 & 6.23 & 9.3 & 0 & 7.7 & 6.3 & 0 & 4.5 & 8 \\
\hline B 12 & 17.9 & 21.7 & 16.7 & 10.03 & 13.7 & 6 & 15.4 & 15.6 & 6 & 26.9 & 17.9 \\
\hline B 13 & 1.3 & 13 & 1.9 & 5.88 & 6.2 & 10 & 3.8 & 6.3 & 10 & 28.4 & 1.8 \\
\hline B 14 & 0 & 4.3 & 1.9 & 0 & 0.6 & 0 & 0 & 0 & 0 & 41.8 & 3.6 \\
\hline B 15 & 10.3 & 4.3 & 9.3 & 5.19 & 9.3 & 22 & 23.1 & 9.4 & 22 & 7.5 & 33 \\
\hline B 16 & 1.3 & 0 & 0 & 0 & 1.2 & 0 & 0 & 0 & 0 & 0 & 0 \\
\hline B 17 & 17.9 & 30.4 & 18.5 & 12.8 & 15.5 & 0 & 3.8 & 21.9 & 0 & 9 & 11.6 \\
\hline B 18 & 3.8 & 8.7 & 5.6 & 2.42 & 9.3 & 0 & 0 & 3.1 & 0 & 0 & 8 \\
\hline B21 & 10.3 & 6.5 & 7.4 & 4.5 & 5.6 & 0 & 0 & 0 & 0 & 0 & 12.5 \\
\hline B22 & 5.1 & 4.3 & 14.8 & 3.81 & 4.3 & 6 & 7.7 & 3.1 & 6 & 6 & 11.6 \\
\hline B27 & 3.8 & 4.3 & 1.9 & 11.76 & 3.7 & 10 & 11.5 & 0 & 10 & 0 & 2.7 \\
\hline B35 & 21.8 & 19.6 & 14.8 & 26.3 & 25.5 & 12 & 30.8 & 25 & 12 & 23.9 & 25.9 \\
\hline B37 & 0 & 2.2 & 1.9 & 5.19 & 1.2 & 6 & 3.8 & 0 & 6 & 1.5 & 0 \\
\hline B40 & 29.5 & 13 & 20.4 & 20.42 & 26.1 & 22 & 38.5 & 43.8 & 22 & 13.4 & 17 \\
\hline B 48 & 0 & 0 & 0 & 0 & 0 & 0 & 0 & 0 & 0 & 0 & 0.9 \\
\hline Cw1 & 2.6 & 2.2 & 3.7 & 7.6 & 0 & $*$ & $*$ & $*$ & $*$ & $*$ & 8.7 \\
\hline Cw2 & 2.6 & 6.5 & 0 & 4.3 & 2.5 & $*$ & $*$ & $*$ & $*$ & $*$ & 8.7 \\
\hline Cw3 & 10.3 & 19.6 & 7.4 & 29.3 & 14.3 & $*$ & $*$ & $*$ & $*$ & $*$ & 13 \\
\hline Cw4 & 30.8 & 34.8 & 25.9 & 19.6 & 31.7 & $*$ & $*$ & $*$ & $*$ & $*$ & 82.6 \\
\hline Cw5 & 0 & 6.5 & 7.4 & 1.1 & 6.2 & $*$ & $*$ & $*$ & $*$ & $*$ & 4.3 \\
\hline Cw6 & 3.8 & 4.3 & 3.7 & 20.7 & 2.5 & $*$ & $*$ & $*$ & $*$ & $*$ & 39.1 \\
\hline Cw7 & 2.6 & 0 & 1.9 & 3.3 & 5 & $*$ & $*$ & $*$ & $*$ & $*$ & 0 \\
\hline DR1 & 0 & 0 & 10.3 & 16.84 & 5.6 & $*$ & $*$ & $*$ & $*$ & $*$ & $*$ \\
\hline DR2 & 51.4 & 22.2 & 37.9 & 50.53 & 33.8 & $*$ & $*$ & $*$ & $*$ & $*$ & $*$ \\
\hline DR3 & 32.4 & 27.8 & 31 & 7.37 & 22.5 & $*$ & $*$ & $*$ & $*$ & $*$ & * \\
\hline DR4 & 21.6 & 11.1 & 24.1 & 8.42 & 33.8 & $*$ & $*$ & $*$ & $*$ & $*$ & $*$ \\
\hline DR5 & 27 & 27.8 & 27.6 & 15.79 & 35.2 & $*$ & $*$ & $*$ & $*$ & $*$ & $*$ \\
\hline DR6 & 5.4 & 0 & 6.9 & 12.63 & 0 & $*$ & $*$ & $*$ & $*$ & $*$ & $*$ \\
\hline DR7 & 29.7 & 44.4 & 24.1 & 29.47 & 35.2 & $*$ & $*$ & $*$ & $*$ & $*$ & * \\
\hline DR8 & 0 & 0 & 0 & 70 & 0 & $*$ & $*$ & $*$ & $*$ & $*$ & $*$ \\
\hline DR9 & 0 & 0 & 0 & 7.37 & 1.4 & $*$ & $*$ & $*$ & $*$ & $*$ & $*$ \\
\hline DR 10 & 0 & 0 & 0 & 14.74 & 0 & $*$ & $*$ & $*$ & $*$ & $*$ & * \\
\hline
\end{tabular}

(Shankarkumar et al. 2002) and Maratha caste (Shankarkumar et al. 2001) revealed that they differ in their allele and haplotype frequencies. This indicates that various caste/tribal population differing in their origins, migration and settlement adopted a belief, like Hinduism and identified themselves with a pre-existing or a new professional group such as Marathas, Bhils, Pawras, Mahars, Kunbis, Jains, Bhramins, Patels, or Parsis. Our recent DNA based HLA class I studies has further confirmed their remarkable level of allelic diversity (Shankarkumar et al. 2002; Shankarkumar et al. 2002).

\section{Differential Disease Susceptibility: Caste System?}

There are few studies that describe the varied HLA disease susceptibility from populations living in the same area. We have compiled the different diseases which have revealed significant HLA associations (Table 3) among western Indians. Further we have reported new novel allele associations in the Western Indian populations (Shankarkumar et al. 2002). We have investigated the association of HLA B27 in Ankylosing spondylitis (Shankarkumar et al. 
Table 2: Percentage gene frequencies among different Indian tribals

\begin{tabular}{|c|c|c|c|c|c|c|c|c|}
\hline$H L A$ & $\begin{array}{r}\text { Orans } \\
N-48 \\
\text { Present }\end{array}$ & $\begin{array}{r}\text { Pawra } \\
N-38 \\
17\end{array}$ & $\begin{array}{r}\text { Bhils } \\
N-53 \\
17 \\
\end{array}$ & $\begin{array}{r}\text { Malayalis } \\
N-42 \\
17\end{array}$ & $\begin{array}{r}\text { Irulas } \\
N-191 \\
17\end{array}$ & $\begin{array}{r}\text { Koya } \\
N-94 \\
17 \\
\end{array}$ & $\begin{array}{r}\text { Kota } \\
N-103 \\
17\end{array}$ & $\begin{array}{r}\text { Badagas } \\
N-58 \\
17\end{array}$ \\
\hline A 1 & 9.9 & 9.7 & 16.4 & 4.9 & 6.8 & 3.7 & 7.77 & 9.48 \\
\hline A 2 & 8.7 & 33.1 & 24.8 & 18.4 & 10.8 & 23.4 & 45.68 & 17.24 \\
\hline A 3 & 11 & 8.2 & 7.9 & 1.2 & 5.1 & 5.3 & 6.8 & 13.79 \\
\hline A9 & 48 & 14.2 & 16.4 & 19.8 & 22.1 & 13.3 & 5.34 & 8.62 \\
\hline A 10 & 0 & 6.8 & 8.9 & 4 & 10.5 & 4.8 & 2.91 & 5.17 \\
\hline A 11 & 12.2 & 14.2 & 9.9 & 22.8 & 18.6 & 28.7 & 16.05 & 13.79 \\
\hline A 19 & 20.9 & 18.9 & 19.9 & 15.1 & 11.9 & 0.5 & 2.91 & 12.07 \\
\hline A 28 & 1 & 5.4 & 3.8 & 8.7 & 2.9 & 1.1 & 0.49 & 5.17 \\
\hline B5 & 13.4 & 4 & 11 & 11.4 & 23.8 & 4.8 & 7.28 & 6.9 \\
\hline B7 & 9.9 & 14.2 & 9.9 & 11.4 & 1.6 & 8 & 15.63 & 3.45 \\
\hline B8 & 0 & 5.4 & 8.9 & 2.4 & 14.1 & 4.3 & 1.46 & 4.31 \\
\hline B 12 & 25 & 4 & 2.9 & 3.6 & 1.1 & 10.1 & 3.4 & 11.21 \\
\hline B 13 & 7.6 & 2.7 & 0.9 & 7.4 & 5.1 & 3.2 & 2.48 & 7.76 \\
\hline B 14 & 0 & 0 & 0 & 0 & 0.3 & 1.6 & 2.91 & 3.45 \\
\hline B 15 & 9.9 & 1.3 & 4.8 & 11.4 & 1.1 & 1.1 & 3.88 & 8.62 \\
\hline B 16 & 0 & $*$ & $*$ & $*$ & $*$ & 1.1 & 0 & 0 \\
\hline B 17 & 4.3 & 8.2 & 8.9 & 11.4 & 8.8 & 25.5 & 2.43 & 3.45 \\
\hline B 18 & 1 & 0 & 0 & $*$ & $*$ & 2.2 & 0.49 & 1.72 \\
\hline B21 & 0 & $*$ & $*$ & $*$ & $*$ & 0.5 & 0 & 0 \\
\hline B22 & 0 & 2.7 & 2.9 & 15.5 & 2.9 & 0.5 & 0.49 & 9.48 \\
\hline B27 & 2.1 & 1.3 & 3.8 & $*$ & $*$ & 1.6 & 1.91 & 4.31 \\
\hline B35 & 20.9 & 17.3 & 11 & 1 & 9.9 & 2.7 & 3.4 & 6.03 \\
\hline B37 & 1 & 4 & 1.9 & 0 & 1.3 & 0 & $*$ & * \\
\hline B40 & 13.4 & 27.5 & 22.3 & 15.5 & 18.5 & 5.3 & 11.17 & 12.07 \\
\hline B53 & 0 & 15.7 & 14.2 & 0 & 4 & 1.1 & * & * \\
\hline
\end{tabular}

* Not reported/ done

All values are percentages. Highest/ higher frequencies of specific allele are indicated in Bold.

Table 3: HLA and disease associations observed in western Indian population

\begin{tabular}{|c|c|c|c|}
\hline$\overline{\text { Disease }}$ & $\begin{array}{r}\text { Associated } \\
\text { HLA }\end{array}$ & $\begin{array}{r}\text { Relative } \\
\text { Risk }\end{array}$ & $\begin{array}{r}\text { Reference } \\
\text { Number }\end{array}$ \\
\hline Leprosy & $\mathrm{B} 40$ & 3.14 & 3 \\
\hline Leprosy & $A * 1102$ & 30 & 37 \\
\hline Multiple Sclerosis (MS) & B 12 & $*$ & 39 \\
\hline Multiple Sclerosis (MS) & $\mathrm{A} 11, \mathrm{~B} 16, \mathrm{Cw} 7$ & $2.6,13.8,5.46$ & 17 \\
\hline Multiple Sclerosis (MS) & $\mathrm{DRB} 1 * 15$ & 16.15 & 17 \\
\hline Lymphoid Leukaemia & B35 & $*$ & 20 \\
\hline $\mathrm{Rh}(\mathrm{D})$ isoimmunization & A3,B17,Cw2,DR4 & 2.6 & 35 \\
\hline Psoriasis & A1,B17,Cw6, & 2.76,3.11,2.98, & 11 \\
\hline Psoriasis & DR7,DQw3 & $2.15,3.16$ & 11 \\
\hline Psoriasis & C4BQ0 & 10.73 & 11 \\
\hline Ankylosing Spondylitis (AS) & B27 & 273 & 4 \\
\hline Ankylosing Spondylitis (AS) & B 27 & 71.5 & 16 \\
\hline Ankylosing Spondylitis (AS) & B27 & 72.22 & 26 \\
\hline Haemophilia with Synovitis & B27 & 34.6 & 34 \\
\hline Systemic Lupus Erythematosus (SLE) & $\mathrm{DRB} * 03, \mathrm{DQB} * 0302$ & $9.67,8.02$ & 36 \\
\hline
\end{tabular}

* Not reported.

All associations were valid in the total Western

Indian populations

Values in Bold are highest Relative risks in a population

2002) and a significantly stronger association with HLA B*2714 was identified among the kunbi caste. The kunbi are landholders and husbandman who earn their living as field laborers, as carriers, as gardeners or house servants. They are mainly distributed among Maharastra State. The association can be attributed to the genetic phenomenon of hitchhiking i.e. the disease spread 
with the migration of the community and the causative genes are linked to the HLA allele. In a similar manner HLA B12 association was observed with multiple sclerosis among Parsis (Trikannad et al. 1982) and other western Indians (Bale et al. 1980, 1982; Mehta et al. 1987; Chablani et al. 1992; Kankonkar et al. 1998; Shankarkumar et al. 2002a, b, 2003; Kankonkar et al. 2003). Thus the origin, migration, sympatric isolation and the resultant divergence of the gene pool at HLA loci add a new dimension to community genetics in terms of disease and prevalence.

\section{DISCUSSION}

The present analysis reveal, the heterogeneous nature of the Indian population suggesting that the population as such or even a linguistic or regional population within it cannot be considered as a panmictic pool; only a caste group may be considered as a homogenous gene pool with its diverse haplotype combinations and high rates of consanguinity. However, it s not known how these HLA allele dependant selection mechanisms might have influenced the disease pathogenesis among the Western Indian population groups. Further studies on nonrecombinant $\mathrm{Y}$ chromosome (NRY) and mitochondria DNA ( $m t$ DNA) alleles can be used to trace migration pattern of different caste and tribal groups of western India.

\section{ACKNOWLEDGEMENTS}

I wish to place on record with gratitude the suggestions and discussions with Dr. J. V. Undevia, Mumbai, in writing this manuscript. Further I would like to thank Prof. T.J. Pandian, Madurai Kamaraj University for his constant support and encouragement.

\section{REFERENCES}

Agwaral S, Arundhati K, Bhardwaj U 1999. HLA antigens and haplotype frequencies in Bhargavas and Chaturvedies of UP (India). Ind J Hum Genet, 5: 25-30.

Balakrishnan K, Pitchappan RM, Suzuki K, Shankarkumar U, Shanthakumari R, Tokunaga K 1996. HLA affinities of Iyers, a Brahmin population of Tamil Nadu, South India. Human Biology, 68: 523-537.

Bale UM, Mehta MM, Contractor NM, Bhatia HM, Koticha KK 1982. HLA antigens in leprosy patients. Tissue Antigens, 20: 141-143.

Bale UM, Mehta MM, Contractor NM, Bhatia HM. Tilve GH 1980. HLA antigens in Ankylosing spondylitis: the association of HLA B27. Indian $J$
Med Res, 71: 96-103.

Bhasin MK, Walter H, Danker-Hopfe H 1994. People of India: An Investigation of Biological Variability in Ecological Ethno-Economic and Linguistic Groups. Delhi: Kamla-Raj Enterprises. pp.1-21.

Bhasin MK, Walter H 2001. Genetics of Castes and Tribes of India. Delhi: Kamla-Raj Enterprises.

Bodmer WF 1987. The HLA system: Structure and function. J Clin Pathol, 40: 948-958.

Boyum A 1968. Separation of leucocytes from blood and bone marrow. Scan J Clin Invest, 21 (Suppl): 97-99.

Cavalli-Sforza LL, Menozzi P, Piazza P 1993. Demic expansion and Human evolution. Science, 259: 639-646.

Chayya SU, Panthaki M, Shankarkumar U 2000. HLA antigen distribution in Gujarathi speaking Hindu population from Mumbai, Maharastra India. Anthropologist, 2: 7-12.

Chayya SU, Shankarkumar U 2001. HLA antigen distribution in Jain community from Mumbai, Maharastra India. Indian J Med Res, 114: 25-29.

Chablani UA, Contractor NM, Gadgil RB 1992. HLA and Complement $\mathrm{C} 4$ studies in psoriasis vulgaris. Nat Med J, 5: 8-11.

Dunn OJ 1961. Multiple comparison among means. Am $J$ Stat Assoc, 56: 52-56.

Einthoven RE (Ed) 1990. The Tribes and Castes of Bombay. New Delhi: Asian Educational Services. pp. $177-418$.

Hill AVS 1998. The immunogenetics of human infectious diseases. Ann Rev Immunol, 16: 593-617.

Jaini R, Naruse T, Kanga U, Kikkawa E, Kaur G, Inoko $\mathrm{H}$, Mehra NK 2002. Molecular diversity if the HLA A19 group of alleles in North India: Possible Oriental influence. Tissue Antigens, 59: 487-491.

Kankonkar SR, Raikar SC, Joshi SV, Tijoriwala SJ 1998. Association of HLA B27 antigen in Indian patients of Ankylosing spondylitis and other autoimmune diseases. JAPI, 46: 345-350.

Kankonkar S, Jeyanthi G, Singhal BS, Shankarkumar U 2003. Evidence for novel DRB $1 * 15$ allele associations among clinically definite Multiple sclerosis patients from Mumbai. Hum Immunol, 64: $478-482$.

Kaufmann J 1996. Evolution of Major Histocompatibility Complex and MHC Like Molecules. In: HLA and MHC: Genes, Molecules and Function. MJ Browning, AJ McMichael (Eds.). Oxford: BIOS Scientific Publishers. pp. 1-17.

Manikasundari M, Selvaraj P, Pitchappan RM 1984. Studies on $\mathrm{T}$ cells of lizard Calotes versicolor. Adherent and non-adherent population of the spleen. Dev Com Immunol, 8: 367-374.

Mehta MM, Contractor NM, Advani SH, Bhatia HM 1987. HLA and surface markers in untreated lymphoid leukemia patients. Indian J Med Res, 85: 415-419.

Pitchappan RM, Kakkaniah VN, Rajasekar R, Arulraj N, Muthukarruppan VR 1984. HLA antigens in South India: I Major groups of Tamil Nadu. Tissue Antigens, 24: $190-196$.

Rajasekar R., Kakkanaiah V.N., Pitchappan R.M 1987. HLA antigens in South India: II Selected caste groups 
of Tamil Nadu. Tissue Antigens, 30: $113-118$

Shankarkumar U, Pednakar SV, Gupte S, Ghosh K, Mohanty D 1999. HLA antigen distribution in Marathi speaking Hindu population from Mumbai, Maharastra, India. J Hum Ecol, 10: 367-372.

Shankarkumar U, Gupte SC, Gupte SS, Pednakar SV, Ghosh K, Mohanty D 1998. Frequency and potential application of HLA antibodies from pregnant women in Mumbai. J Biosci, 23: 601-604.

Shankarkumar U 2002. HLA A19 and B14 frequencies among Parsis from Mumbai. MHC, 9: 77-82.

Shankarkumar U, Ghosh K, Gupte S, Mukerjee MB, Mohanty D 1999. Distribution of HLA antigens in Bhils and Pawras of Dhadgaon Maharastra, India. $J$ Hum Ecol, 10: 173-178.

Shankarkumar U, Ghosh K, Mohanty D 2000. HLA Class I antigen profile among Brahmins and related caste groups from Mumbai, Maharastra, India. Indian J Human Genet, 6: 12-17.

Shankarkumar U, Ghosh K, Mohanty D 2001. HLA antigen distribution in Maratha community from Mumbai, Maharastra India. Int J Hum Genet, 1: 173-177.

Shankarkumar U, Devaraj JP, Ghosh K, Mohanty D 2002a. Seronegative spondarthritis (SSA) and HLA association. Br J Biomed Sci, 59: 38-41.

Shankarkumar U, Ghosh K, Colah RB, Gorakshakar AC, Gupte SC, Mohanty D 2002b. HLA antigen distribution in selected caste groups from Mumbai. Maharastra India. J Hum Ecol, 13: 209-215.
Shankarkumar U, Ghosh K, Mohanty D 2002c. Defining the allelic variants of HLA A19 in the western Indian population. Human Immunol, 63: 779-782.

Shankarkumar U, Ghosh K, Mohanty D 2002d. HLA B27 diversity from Western India. Tissue Antigens, 60: $98-101$.

Shankarkumar U, Ghosh K, Shetty S, Mohanty D 2002e. HLA B*2708 is strongly associated in severe hemophilia patients with chronic synovitis. Human Immunol, 63: S58.

Shankarkumar U, Ghosh K, Gupte SS, Gupte SC, Mohanty D 2002f. Role of HLA antigen in Rh (D) alloimmunised pregnant women from Mumbai. $J$ Biosci, 27: 135-141.

Shankarkumar U, Ghosh K, Badakere SS, Mohanty D 2003a. HLA DRB $1 * 03$ and $\mathrm{DQB} 1 * 0302$ associations in a subset of patients severely affected with systemic lupus erythematosus from western India. Ann Rheum Dis, 62: 92-93.

Shankarkumar U, Ghosh K, Badakere S, Mohanty D 2003b. Novel HLA Class I alleles associated in Indian leprosy patients. J Biomed Biotech, 3: 208211.

Terasaki PI, Mc Clelland JD 1964. Microdroplet assay of human serum cytotoxins. Nature, 204: 998-1000.

Trikannad VS, Wadia NH, Krishnaswamy PR 1982. Multiple sclerosis and HLA B12 in Parsi and nonParsi Indians: A clarification. Tissue Antigens, 19: 155-157. 